\title{
The activity of antioxidant enzymes in colorectal adenocarcinoma and corresponding normal mucosa
}

\author{
Joanna Katarzyna Strzelczyk ${ }^{1 凶}$, Tomasz Wielkoszyński², Łukasz Krakowczyk³, \\ Brygida Adamek', Marzena Zalewska-Ziob1, Katarzyna Gawron', Janusz Kasperczyk4, \\ and Andrzej Wiczkowski ${ }^{1}$
}

\begin{abstract}
'Chair and Department of General Biology, Medical University of Silesia, Zabrze, Poland; 2Department of Chemistry, Medical University of Silesia, Zabrze, Poland; ${ }^{3}$ Clinic of Oncological and Reconstructive Surgery, Maria Sklodowska-Curie Memorial Cancer Center and Institute of Oncology, Gliwice Branch, Gliwice, Poland; ${ }^{4}$ Chair and Department of Environmental Medicine and Epidemiology, Medical University of Silesia, Zabrze, Poland
\end{abstract}

Oxidative stress is one of several factors which contribute to the development of colorectal carcinogenesis. The aim of the study was an assessment of the activity of antioxidant enzymes in tumour and corresponding normal distal mucosa in a group of patients with colorectal adenocarcinoma. Samples of tumour and corresponding normal mucosa were obtained during a resection of colorectal cancer from 47 patients aged between 26 and 82 years. The average distance of corresponding normal distal mucosa from the tumour was $4.49 \mathrm{~cm}$. Activities of antioxidant enzymes: superoxide dismutase (SOD), glutathione reductase (GR), glutathione peroxidase (GPx), glutathione S-transferase (GST), and catalase (CAT) were measured in tissue homogenates. The patients were grouped according to the tumour stage (Duke's staging), grading, localization, and size of tumour, as well as age and sex. Statistical analysis was performed. The activity of SOD and GPx was considerably increased, while the activity of GST decreased significantly in tumour as compared with normal mucosa. GR activity in colorectal cancer was evidently higher in tumours of proximal location compared with the distal ones. The distance of corresponding normal distal mucosa from the tumour was analyzed and related to all assayed parameters. A decreased GST activity was observed in corresponding normal mucosa more than $5 \mathrm{~cm}$ distant from the tumour in patients with CD Duke's stage. The higher activity of superoxide dismutase and glutathione peroxidase in tumour compared to corresponding normal mucosa could indicate higher oxidative stress in colorectal adenocarcinoma cells.

Key words: oxidative stress, antioxidant enzymes, colorectal adenocarcinoma, corresponding normal mucosa

Received: 12 December, 2011; revised: 25 July, 2012; accepted: 31 October, 2012; available on-line: 27 November, 2012

\section{INTRODUCTION}

Oxygen is an element essential for life, however, owing to its potent chemical activity, some by-products of oxygen metabolism are toxic to living organisms. These include reactive oxygen species (ROS), some are free radicals (Abele, 2002; Valko et al., 2007). Reactive oxygen species include the superoxide anion radical ${ }^{\circ} \mathrm{O}_{2}^{-}$, hydroxyl radical $\left({ }^{\circ} \mathrm{OH}\right)$, singlet oxygen $\left({ }^{1} \mathrm{O}_{2}\right)$, hydrogen peroxide $\left(\mathrm{H}_{2} \mathrm{O}_{2}\right)$, and hypochlorous acid (I) (HOCl) (Halliwell \& Gutteridge, 1999; Zasadowski et al., 2004).
Oxidative stress is defined as a lack of equilibrium between the oxidative agents (pro-oxidants) and antioxidants, compounds that protect biomolecules against the harmful effects of pro-oxidants (Klaunig \& Kamendulis, 2004). When ROS production exceeds their utilization capacity, that leads to damage of nucleic acids, proteins and lipids, which in turn results in a disruption of cell, tissue or organ functions (Evans et al., 2004; Tanaka et al., 2007; Valko et al., 2007).

The cells of eukaryotic organisms have developed defence mechanisms that limit the level of ROS and the damage caused by their activity. Those defence mechanisms include antioxidant enzymes, such as superoxide dismutase (SOD), glutathione reductase (GR), glutathione peroxidise (GPx), glutathione S-transferase (GST), and catalase (CAT). These enzymes are present in various isoforms, in the intracellular and extracellular compartments, and their activity creates an integrated antioxidant defence system. Cells are also protected against oxidative stress by a system of non-enzymatic free radical scavengers, such as ascorbic acid, reduced glutathione, $\beta$-carotene, $\alpha$-tocopherol, and cytochrome $c$ (Zasadowski et al., 2004; Valko et al., 2007).

It has been shown that increased oxidative stress plays a role in the pathomechanism of many diseases, including senile cataract, atherosclerosis, diabetes, and degenerative brain disorders (Craghill et al., 2004; Singh et al., 2004; Dalle-Donne et al., 2005; Violi \& Cangemi, 2005; Ceriello, 2006; Lin \& Beal, 2006). Excessive synthesis of reactive oxygen species or inadequacy of the antioxidant defence system mechanisms are also aetiological factors in carcinogenesis (Cerutti, 1994; Ray et al., 2000; Liu et al., 2003; Klaunig \& Kamendulis, 2004; Lu, 2007). The strongest ROS involvement, resulting from the exposition of organs to the activity of environmental pro-oxidants, has been demonstrated in the aetiology of bronchial and gastrointestinal tract cancers (Vanisree \& Shyamaladevi, 1999; Kamp et al., 2001; Skrzydlewska et al., 2003; Dincer et al., 2007; Inayama et al., 2007; Rainis et al., 2007).

In addition to ROS, cell oxidants include reactive forms of nitrogen (RNS, reactive nitrogen species) such as the nitric oxide radical $\left(\mathrm{NO}^{*}\right)$ and peroxynitrite (III) $\mathrm{ONOO}^{-}$, which are also thought to contribute to the

e-mail: asia.strzelczyk@gmail.com

Abbreviations: CAT, catalase; GPx, glutathione peroxidase; GR, glutathione reductase; GST, glutathione $S$-transferase; ROS, reactive oxygen species; SOD, superoxide dismutase. 
development of cancer (Klatt \& Lamas, 2000; Hofseth et al., 2003; Dalle-Donne et al., 2006; Beevi et al., 2007; Patel et al., 2009). Zafirellis et al. (2010) examined the inducible nitric oxide synthase (iNOS) expression in colorectal cancer and found that it could be a prognostic factor.

It is postulated that ROS are crucial factors in the initiation, promotion and progression of the carcinogenic process (Ray \& Husain, 2002; Evans et al., 2004; Pervaiz, 2006; Laviano et al., 2007). As early as 1984, Zimmerman \& Cerutti (1984) demonstrated that exposure of mouse fibroblasts to reactive oxygen species may lead to neoplastic transformation. An increased level of oxidative damage to neoplastic cells may be a result of: (I) increased ROS production in the absence of antioxidant system dysfunction, (II) a stable ROS level combined with a reduced efficiency of the antioxidant system, (III) errors in the DNA oxidative damage repair system, (IV) a combination of the above (Klaunig \& Kamendulis, 2004; Halliwell, 2007; Karihtala \& Soini, 2007).

Studies have shown that high production of ROS and the resulting oxidative stress are characteristic for neoplastic cells, both in vivo and in vitro (Szatrowski \& Nathan, 1991; Toyokuni, 1998; Zhou et al., 2003; Hileman et al., 2004; Pelicano et al., 2004; Bechtel \& Bauer, 2009) and the results of studies by Kondo et al. (1999) have demonstrated an increased level of ROS in adenocarcinoma compared to colon adenoma. Epithelial cells that line the intestine are in direct contact with oxygen radicals originating from diet or those produced by intestinal microflora (Skrzydlewska et al., 2001). Excessive ROS production, connected with the phagocyte 'oxidative burst', as well as a rising level of ROS in the defective vascular system in the vicinity of the neoplastic lesion, are the main causes of an increased level of ROS in neoplastic cells when compared to adjacent "healthy" tissues (Ray \& Husain, 2002). Furthermore, the intensified metabolic activity of neoplastic cells also translates into increased production of the superoxide anion radical (Spitz et al., 2000). There are limited reports on the prooxidant-antioxidant balance in cancerous tissue of $\mathrm{pa}$ tients with colorectal cancer (Kanbagli et. al, 2000) and the precise mechanisms of oxidative stress and the role of ROS are still not fully understood (Skrzydlewska et al., 2005). Therefore, the aim of our study was to assess the activity of antioxidant enzymes in tumour and in corresponding normal distal mucosa tissues in patients with colorectal adenocarcinoma.

\section{MATERIALS AND METHODS}

Patients. The study group consisted of 47 patients aged 26-82 years (mean age 65 years) with a preoperative diagnosis of colorectal cancer, based on imaging and histopathological examination of specimens. The group consisted of 20 women and 27 men, that is $43 \%$ and $57 \%$ of the studied cases, respectively.

Patients with diabetes, diseases of the gastrointestinal tract, pancreas or liver, lipid metabolism disorders or acute infections, as well as tobacco smokers, were excluded from the study group. Hereditary and familial factors associated with the development of colorectal cancer were also eliminated. Patients did not receive preoperative radio-chemotherapy.

Specimens. Tissue specimens from both tumour and corresponding normal mucosa were obtained during resection of neoplastic lesions at the Clinic of Oncological and Reconstructive Surgery of the Maria Sklodowska-
Curie Memorial Cancer Center \& Institute of Oncology in Gliwice. The normal mucosa was obtained from a distal segment of resected colon, at a distance of at least 2 $\mathrm{cm}$ from the tumour, the average distance of that distal margin was $4.49 \mathrm{~cm}$. The specimens were placed in ice and transported promptly to the laboratory, where they were washed twice with cold $0.9 \% \mathrm{NaCl}$. Subsequently, they were divided into two smaller fragments of which one was frozen at $-80^{\circ} \mathrm{C}$, and the second was examined histopathologically.

Homogenisation. The tissue fragment (30-80 mg) was homogenised using a PRO 200 homogeniser (PRO Scientific Inc, USA) for 60 seconds at 10000 RPM (5 times with 2-minute intervals) in nine volumes of icecold homogenisation buffer. For SOD assaying, $20 \mathrm{mM}$ Hepes buffer, pH 7.2 (PAA, Austria) was used. Phosphate-buffered saline solution (PBS without $\mathrm{Ca}$ and $\mathrm{Mg}$, BIOMED, Poland) containing 0.5\% Triton $^{\circledR}$ X-100 (Sigma-Aldrich ${ }^{\circledR}$, USA) was used for total protein, GR, GPx, GST, and CAT activity determinations. Subsequently, the obtained homogenates were centrifuged at $12000 \times g$ for 15 minutes at $+4{ }^{\circ} \mathrm{C}$, the supernatants were divided into appropriate portions and frozen at $-80^{\circ} \mathrm{C}$ until required for further testing.

Enzyme activity. The activities of superoxide dismutase, glutathione reductase, glutathione peroxidase, glutathione $S$-transferase and catalase were estimated in units/g protein. The total protein content was determined with the pyrogallol-red method using a set of reagents for direct colorimetric measurements of total protein (Sentinel Diagnostics, Italy). The coefficient of variation for the total protein determination assay was $2.07 \%$.

Superoxide dismutase - SOD (cytosolic $\mathrm{Cu} / \mathrm{Zn}$ SOD isoenzyme and mitochondrial Mn-SOD isoenzyme, EC 1.15.1.1) activity was measured spectrophotometrically using the Superoxide Dismutase Assay Kit (Cat. No. 706002, Cayman Chemical Company, USA) in accordance with the kit protocol. Absorbance readings were obtained using an ELISA PowerWave XSTM reader (BioTek ${ }^{\circledR}, \mathrm{USA}$ ) at $450 \mathrm{~nm}$ wavelength. Assays were performed in duplicate and the coefficient of variation between duplicate samples ranged from 3.1\% to 9.6\%. Glutathione reductase (GR, EC 1.6.4.2) activity was measured at $37^{\circ} \mathrm{C}$ according to the Bioxytech S.A. (France) assay kit instructions using a kinetic-spectrophotometric method. The coefficient of variance for the GR assay was $4.21 \%$. Glutathione peroxidase (GPx, GSH-Px, EC 1.11.1.6) activity was determined using a kinetic-spectrophotometric method in accordance with the Bioxytech S.A. (France) assay kit instructions. The coefficient of variation for the GPx assay was $1.82 \%$. Total (cytosolic and microsomal) glutathione $S$-transferase (GST, EC 2.5.1.18) activity was determined using a kinetic-spectrophotometric method in accordance with the Cayman Chemical Company (USA, Cat. No. 703302) assay kit instructions. The assay is based on a method according to Habig et al. (1974), with 1-chloro-2,4-dinitrobenzene as a substrate. The coefficient of variation for the GST assay was $2.73 \%$. The determinations of glutathione peroxidise, reductase and $S$-transferase activities and total protein concentration were done at $37^{\circ} \mathrm{C}$ with use Technicon RA-XT ${ }^{\mathrm{TM}}$ biochemical analyser (Technicon Instruments Corporation, USA). For the determination of catalase (CAT, EC 1.11.1.9) activity, a spectrophotometric method was used with purpald reagent (4-amino-3-hydrazino-5-mercapto-1,2,4-triazole) based on the method of Johansson and Borg (1988). Absorbance readings were obtained with ELISA PowerWave XS ${ }^{\mathrm{TM}}$ (BioTek ${ }^{\circledR}$, USA) at $550 \mathrm{~nm}$ wavelength. 
Readings were taken at $20^{\circ} \mathrm{C}$. Calibration was performed using formaldehyde standards (POCH, Poland) at concentrations ranging from $8 \mu \mathrm{mol} / \mathrm{L}$ to $512 \mu \mathrm{mol} / \mathrm{L}$. The coefficient of variation for the CAT assay was $6.8 \%$.

Histopathology. Histopathological evaluation of the samples was performed at the Tumour Pathology Department of the Maria Sklodowska-Curie Memorial Cancer Center \& Institute of Oncology, Gliwice Branch, and histopathological confirmation of colorectal adenocarcinoma was obtained in all patients while the presence of neoplastic cells in the distal margins was excluded. In $37(79 \%)$ of cases the tumour was located in the distal section of the colon while $10(21 \%)$ of tumours were located in the proximal section (the dividing line being the splenic flexure). The average size of the tumour in the study group was $4.67 \mathrm{~cm}$. Depending on the tumour staging according to Dukes, patients were divided into two subgroups. The first subgroup consisted of 27 (57\%) of patients with A and B Dukes' staging; the second subgroup comprised $20(43 \%)$ of patients with C and D Dukes' staging. Histopathological evaluation revealed $11(24 \%)$ cases of well/highly differentiated (G1) cancer, $33(70 \%)$ cases of moderately differentiated (G2) cancer, and $3(6 \%)$ poorly/lowly differentiated (G3) cancer. The histopathological examination did not reveal the presence of any lymphocytic infiltration in the area around the tumours, thus eliminating the possibility of local inflammation. The study project was approved by the Bioethics Committee of the Maria SklodowskaCurie Memorial Cancer Center \& Institute of Oncology, Gliwice Branch (No. D0/DGP/493-10/05 and No. $\mathrm{KB} / 493-54 / 07)$. The patients were acquainted with the protocol after which they signed an informed consent document to participate in the study.

Statistical analysis. The statistical analysis was performed using Statistica 7.1PL software. Statistical comparisons were made using Student's $t$-test. Values of $p<0.05$ were considered significant.
Table 1. Activity of antioxidant enzymes superoxide dismutase (SOD), glutathione reductase (GR), glutathione S-transferase (GST), catalase (CAT), and glutathione peroxidase (GPx) in homogenates of tissues obtained from colorectal tumours and distal margins in patients with colorectal adenocarcinoma

\begin{tabular}{llll}
\hline Assayed parameter & $\begin{array}{l}\text { Tumour } \\
\bar{X} \pm \text { S.D. }\end{array}$ & $\begin{array}{l}\text { Distal margin } \\
\bar{X} \pm \text { S.D. }\end{array}$ & $p$-value \\
\hline SOD [U/g protein] & $88.9 \pm 40.69$ & $58.4 \pm 29.23$ & $<0.001$ \\
GR [U/g protein] & $71.3 \pm 44.84$ & $58.0 \pm 42.20$ & 0.159 \\
GST [U/g protein] & $31.0 \pm 22.11$ & $42.5 \pm 23.45$ & 0.021 \\
CAT [U/g protein] & $114.2 \pm 63.48$ & $103.4 \pm 53.13$ & 0.386 \\
GPx [U/g protein] & $54.5 \pm 66.96$ & $22.8 \pm 23.99$ & 0.004 \\
\hline
\end{tabular}

$\overline{\bar{X}}$, means; S.D., standard deviation

\section{RESULTS}

The activity of SOD and GPx was considerably higher in homogenates obtained from tumours compared to the activity in distal margins. Conversely, GST activity was lower in tumour homogenates, than in distal margin homogenates. No significant differences were found between tumour and distal margin for GR or CAT activity (Table 1). Furthermore, our findings revealed there were no significant differences between the activity of the majority of the enzymes tested in relation to the tumour staging (according to Dukes' classification), grading, their localisation or size, as well as the patients' age or sex (Table 2, 3, and 4). Only the GR activity was found to be statistically significantly higher in tumours with proximal location than in those of distal location $(p=0.013$; Table 4). All assayed parameters were also analysed for any relation to the distance between the tumour and distal margin (Table 2, 3, and 4). The only significant

Table 2. Activity of antioxidant enzymes superoxide dismutase (SOD) and catalase (CAT) in homogenates of tissues obtained from colorectal tumours and distal margins in relation to clinical parameters in patients with colorectal adenocarcinoma

\begin{tabular}{|c|c|c|c|c|c|c|}
\hline & & \multicolumn{3}{|c|}{$\begin{array}{l}\text { SOD [U/g protein] } \\
\bar{X} \pm \text { S.D. }\end{array}$} & \multicolumn{2}{|c|}{$\begin{array}{l}\text { C.AT [U/g protein] } \\
\bar{X} \pm \text { S.D. }\end{array}$} \\
\hline & & $\mathrm{N}$ & Tumour & Distal margin & Tumour & Distal margin \\
\hline Women & & 20 & $94.7 \pm 43.8$ & $63.1 \pm 29.8$ & $109.4 \pm 51.5$ & $113.6 \pm 66.3$ \\
\hline Men & & 27 & $84.6 \pm 38.4$ & $55 \pm 28.8$ & $117.6 \pm 71.7$ & $95.6 \pm 40.1$ \\
\hline \multirow[t]{2}{*}{ Age } & $<65$ & 17 & $88.7 \pm 35.1$ & $55 \pm 29.8$ & $115.6 \pm 86.4$ & $115.3 \pm 63.2$ \\
\hline & $>65$ & 30 & $88.9 \pm 44.0$ & $60.3 \pm 29.2$ & $113.4 \pm 48.2$ & $97.2 \pm 47.1$ \\
\hline \multirow[t]{2}{*}{ Tumour localisation } & Proximal & 10 & $93.3 \pm 43.3$ & $57.7 \pm 30.7$ & $104.4 \pm 59.1$ & $110 \pm 44.7$ \\
\hline & Distal & 37 & $87.7 \pm 40.5$ & $58.6 \pm 29.2$ & $116.6 \pm 65$ & $101.7 \pm 55.5$ \\
\hline \multirow[t]{2}{*}{ Tumour staging (Dukes' classification) } & $A, B$ & 27 & $90 \pm 38.5$ & $56.9 \pm 26.9$ & $113.8 \pm 60.3$ & $97.6 \pm 50.5$ \\
\hline & $C, D$ & 20 & $87.3 \pm 44.4$ & $60.5 \pm 32.7$ & $114.7 \pm 69.2$ & $111 \pm 56.8$ \\
\hline \multirow[t]{3}{*}{ Grading } & G1 & 11 & $85 \pm 53.4$ & $60 \pm 33.3$ & $95 \pm 19.2$ & $112.8 \pm 60.4$ \\
\hline & $\mathrm{G} 2$ & 33 & $91.7 \pm 40.5$ & $57 \pm 31.8$ & $122.1 \pm 70.3$ & $100 \pm 54.5$ \\
\hline & G3 & 3 & $130 \pm 14.1$ & $75 \pm 7$ & $70 \pm 0$ & $120 \pm 14.1$ \\
\hline \multirow[t]{2}{*}{ Distance from distal margin to tumour } & $\leq 5 \mathrm{~cm}$ & 14 & $84.7 \pm 38$ & $55.8 \pm 27.9$ & $102.9 \pm 56.5$ & $103.3 \pm 48.5$ \\
\hline & $>5 \mathrm{~cm}$ & 33 & $106 \pm 47.8$ & $70 \pm 32.3$ & $145 \pm 76.1$ & $104 \pm 71.3$ \\
\hline
\end{tabular}

$\overline{\bar{X}}$, means; S.D., standard deviation 
Table 3. Activity of glutathione peroxidase (GPx) in homogenates of tissues obtained from colorectal tumours and distal margins in relation to clinical parameters in patients with colorectal adenocarcinoma

\begin{tabular}{|c|c|c|c|c|}
\hline & & \multicolumn{3}{|c|}{$\begin{array}{l}\text { GPx [U/g protein] } \\
\bar{X} \pm \text { S.D. }\end{array}$} \\
\hline & & $\mathrm{N}$ & Tumour & Distal margin \\
\hline Women & & 20 & $60.3 \pm 88.9$ & $22.1 \pm 22.3$ \\
\hline Men & & 27 & $50 \pm 45.2$ & $22.3 \pm 24.5$ \\
\hline \multirow[t]{2}{*}{ Age } & $<65$ & 17 & $49 \pm 55.6$ & $28.2 \pm 28.8$ \\
\hline & $>65$ & 30 & $57.5 \pm 73.4$ & $19.7 \pm 20.6$ \\
\hline \multirow[t]{2}{*}{ Tumour localisation } & Proximal & 10 & $67.7 \pm 98.6$ & $14.8 \pm 12.9$ \\
\hline & Distal & 37 & $51.5 \pm 59.2$ & $24.6 \pm 25.6$ \\
\hline \multirow[t]{2}{*}{ Tumour staging (Dukes' classification) } & $A, B$ & 27 & $55.1 \pm 65.9$ & $24.8 \pm 23.6$ \\
\hline & C, D & 20 & $53.4 \pm 70.3$ & $20 \pm 24.8$ \\
\hline \multirow[t]{3}{*}{ Grading } & G1 & 11 & $63.7 \pm 100$ & $25.8 \pm 27.4$ \\
\hline & G2 & 33 & $45 \pm 43.9$ & $23 \pm 25.5$ \\
\hline & G3 & 3 & $55 \pm 35.3$ & $22 \pm 25.4$ \\
\hline \multirow[t]{2}{*}{ Distance from distal margin to tumour } & $\leq 5 \mathrm{CM}$ & 14 & $46.5 \pm 53.3$ & $21 \pm 24.3$ \\
\hline & $>5 \mathrm{CM}$ & 33 & $76.2 \pm 101.5$ & $26.6 \pm 22.9$ \\
\hline
\end{tabular}

$\overline{\bar{X}}$, means; S.D., standard deviation

relation found was in GST activity in margin samples, it depended on the distance from the tumour and on Dukes' staging. In the group of patients with the CD Dukes' staging, the GST activity was lower in the distal margins separated from the tumour by more than 5 $\mathrm{cm}$ than in the less distant distal margins $(50.7 \pm 25.86 \mathrm{vs}$. $20.0 \pm 10.00 ; p=0.049)$.

Table 4. Activity of antioxidant enzymes glutathione reductase (GR) and glutathione S-transferase (GST) in homogenates of tissues obtained from colorectal tumours and distal margins in relation to clinical parameters in patients with colorectal adenocarcinoma

\begin{tabular}{|c|c|c|c|c|c|c|}
\hline & & \multirow[b]{2}{*}{$\mathrm{N}$} & \multicolumn{2}{|c|}{$\begin{array}{l}\text { GR [U/g protein] } \\
\bar{X} \pm \text { S.D. }\end{array}$} & \multicolumn{2}{|c|}{$\begin{array}{l}\text { GST [U/g protein] } \\
\bar{X} \pm \text { S.D. }\end{array}$} \\
\hline & & & Tumour & Distal margin & Tumour & Distal margin \\
\hline Women & & 20 & $72.6 \pm 43.3$ & $59.0 \pm 32.2$ & $28.9 \pm 23.9$ & $46.1 \pm 25.4$ \\
\hline Men & & 27 & $70.2 \pm 46.9$ & $57.3 \pm 48.5$ & $32.5 \pm 21$ & $39.9 \pm 22.1$ \\
\hline \multirow[t]{2}{*}{ Age } & $<65$ & 17 & $58 \pm 43.4$ & $51.2 \pm 35.7$ & $24.2 \pm 16.6$ & $43.3 \pm 23.5$ \\
\hline & $>65$ & 30 & $78.3 \pm 44.7$ & $61.8 \pm 45.6$ & $34.6 \pm 24$ & $42 \pm 23.8$ \\
\hline \multirow[t]{2}{*}{ Tumour localisation } & Proximal & 10 & $96.2 \pm 26.69$ & $63.6 \pm 46.4$ & $35.8 \pm 27.5$ & $37.5 \pm 30.1$ \\
\hline & Distal & 37 & $65.5 \pm 46.44$ & $56.5 \pm 41.6$ & $29.7 \pm 20.7$ & $43.5 \pm 22$ \\
\hline \multirow[t]{2}{*}{ Tumour staging (Dukes' classification) } & $A, B$ & 27 & $63.2 \pm 42.8$ & $54.8 \pm 42.4$ & $31 \pm 22.6$ & $40.3 \pm 22$ \\
\hline & $C, D$ & 20 & $83.5 \pm 46.3$ & $62.2 \pm 42.6$ & $31 \pm 22$ & $45.5 \pm 25.7$ \\
\hline \multirow[t]{3}{*}{ Grading } & G1 & 11 & $51.2 \pm 18.8$ & $55 \pm 37.4$ & $21.8 \pm 15.5$ & $32.5 \pm 12.8$ \\
\hline & G2 & 33 & $67.6 \pm 48.2$ & $47.4 \pm 34$ & $30.8 \pm 21.17$ & $44.6 \pm 23.9$ \\
\hline & G3 & 3 & $120 \pm 14.1$ & $95 \pm 21.2$ & $36.5 \pm 33.7$ & $50 \pm 14.1$ \\
\hline \multirow[t]{2}{*}{ Distance from distal margin to tumour } & $\leq 5 \mathrm{~cm}$ & 14 & $68.5 \pm 48.8$ & $61.2 \pm 44$ & $31.2 \pm 22.5$ & $43.4 \pm 21.5$ \\
\hline & $>5 \mathrm{~cm}$ & 33 & $81 \pm 32.1$ & $51.3 \pm 37.1$ & $31.4 \pm 22.8$ & $38.1 \pm 31.8$ \\
\hline
\end{tabular}

$\overline{\bar{X}}$, means; S.D., standard deviation

\section{DISCUSSION}

Oxidative stress is considered to be of vital importance among factors playing a role in the process of carcinogenesis in the colon (Kanbagli et al., 2000; Bartsch et al., 2002; Skrzydlewska et al., 2003; Rainis et al., 2007). One of the indications of oxidative stress is lipid peroxidation, a process where polyunmake up phospholipids, undergo an oxidative reaction resulting in the formation of their peroxides. The end products of lipid hydroxylation, such as aldehydes and alcohols, impair protein synthesis and may have an adverse effect on membrane permeability, hemotactic activity and immunological redulis, 2004; Zasadowski et al., 2004; Karihtala \& Soini, 2007). Lipid peroxidation is considered to be an important factor responsible for endothelial function and vasotonus regulation (Zasadowski et al., 2004). It has been demonstrated that elderly people have an elevated lipid peroxide content in the intestinal lumen, and a positive correlation has been found between fat consumption and the incidence of malignant breast, ovarian and colon cancer in elderly people. Reacsaturated fatty acids, which sponse (Klaunig \& Kamen- 
tive oxygen species may be obtained from foods with a high content of polyunsaturated fatty acids, which are a source of lipid peroxides, or may be produced by the intestinal microflora (Skrzydlewska \& Stankiewicz, 2001; Dincer et al., 2007; Rainis et al., 2007). Animal studies have shown that a diet rich in fat is conductive to the neoplastic transformation of colon adenoma (Nicholson et al., 1991). The development of some cancers is also connected with chronic inflammatory conditions which are accompanied by the release of significant amounts of ROS and RNS. They are formed through a defence mechanism, created by phagocytes accumulating in the intestinal mucosa in patients with chronic inflammatory diseases. Upon activation, phagocytes produce oxidants whose presence increases the risk of cancer development (Wiseman et al., 1996; Seven et al., 2000; Roessner et al., 2008). Simmonds et al. (1992) documented an augmented production of reactive oxygen species in intestinal biopsy specimens of patients with the inflammatory bowel disease. Seven et al. (2000) also observed increased lipid peroxidation in rectal biopsy specimens of patients with active ulcerative colitis. Moreover, ROS stool content was increased when a diet rich in fats and low in dietary fibre was consumed (Ehardt et al., 1997).

Our analysis of antioxidant enzyme activity revealed a considerable increase in SOD and GPx activity in specimens obtained from tumours when compared with margins. Superoxide dismutase and glutathione peroxidase comprise the first line of the antioxidant defence system and are the main enzymes catalysing ROS decomposition reactions. Therefore, they play an important role in protecting the organism against oxidative damage (Singh, 1997). The presented results are consistent with the data reported by Skrzydlewska et al. (Skrzydlewska \& Stankiewicz, 2001; Skrzydlewska et al., 2003; 2005), Ozdemirler et al. (1998), Kanbagli et al. (2000) and Satomi et al. (1995). Those authors have also recorded a considerable increase in SOD activity in neoplastic tissues compared to margins in a group of patients with colorectal cancers, including adenocarcinoma. Janssen et al. (1999) found higher MnSOD activity in colorectal cancer with liver metastases compared to the activity of this enzyme in adenomas and normal colon mucosa. Moreover, other authors have noted higher SOD activity in gastric carcinoma, primary liver tumours and brain tumours (Janssen et al., 2000; Czeczot et al., 2003; Wang et al., 2005; Dudek et al., 2004; Kekec et al., 2009). GPx activity determinations in colorectal adenocarcinoma specimens performed by Kanbagli et al. (2000), Skrzydlewska et al. (Skrzydlewska \& Stankiewicz, 2001; Skrzydlewska et al., 2003) and Erata et al. (2005) have shown a statistically significantly higher activity of that enzyme compared to the activity in the tumour margin. Similar differences in GPx activity in colorectal cancer specimens compared to the tumour margin have also been reported by other authors (Ozdemirler et al., 1998; Stanczyk et al., 2005; Rainis et al., 2007; Kekec et al., 2009). However, we found in tumour specimens a decreased glutathione S-transferase enzyme activity in comparison to that of the distal margin. Other authors have also observed a decreased GST activity in cancers (Das et al., 2007; Sharma et al., 2007).

We did not observe any significant differences in glutathione reductase activity between tumour and distal margin. Studies by other authors showed that GR activity was statistically significantly higher in tumour tissue of patients with colorectal cancer as compared to the tumour margin (Skrzydlewska \& Stankiewicz, 2001; Stanczyk et al., 2005). However, in the case of various types of brain tumours and in a group of patients with cervi- cal cancer, the GR activity in patients' blood was lower than in the control group of healthy subjects (Rao et al., 2000; Sharma et al., 2007). Our results show a statistically higher GR activity in tumours located in the proximal segment of the colon compared to the GR activity in tumours of distal location. The difference in the GR activity depending on the tumour location may be connected with different levels of functional activity in the respective segments of the colon. Moreover, an evaluation of catalase activity did not reveal substantial differences between tumour and distal margin in analysed cases of colorectal adenocarcinoma. Rainis et al. (2007) and Beno et al. (1995) noted increased CAT activity in adenoma and colorectal cancer specimens. Hwang et al. (2007) observed an increase in CAT expression in gastric adenocarcinoma cells compared to the normal tissue.

The presented study also analyzed the relation between the activity of the studied enzymes and the tumour stage (according to Dukes' classification), grading, the size and localisation of the tumour, as well as patients' age and sex. There were no statistically significant differences. The study results corroborate the conclusions of Erata et al. (2005) carried out in a group of patients with colorectal adenocarcinoma, which revealed no connection between the tumour stage and histological tumour differentiation and GPx activity in tumour specimens. Similarly, an absence of a significant relationship between the parameters mentioned above and antioxidant enzyme activity was reported by Dincer et al. (2007) in patients with gastric and colorectal carcinoma. A lack of differences in SOD and CAT activity depending on the tumour stage was also demonstrated by Ho et al. (2006) in a group of patients with lung cancer and by Dursun et al. (2006) between SOD, GPx and CAT activities in patients with oesophageal and gastric carcinoma. However, other studies performed on a group of patients with colorectal cancer noted an increased in antioxidant enzyme activity correlated with the tumour stage as well as histological tumour differentiation (Satomi et al., 1995; Stanczyk et al., 2005).

The incidence of cancer increases with age, affecting approximately $35 \%$ of people over 85 years old. Reactive oxygen species are considered to be a key element of cellular disorganisation occurring in the elderly (Savitha et al., 2005; Humphries et al., 2006). Studying on rats, Savitha et al. (2005) observed a significant decrease in antioxidant enzyme levels with age. The present study did not, however, reveal such differences; this is also consistent with observations of other authors (Dincer et al., 2007; Hwang et al., 2007). The present study also analysed the relation between the distance from the tumour to the sampled margin and the studied parameters. That analysis revealed only a significant difference in the GST activity and in relation to the tumour staging according to Dukes' classification. Observations in the group of patients with CD Dukes' staging revealed lower GST values in margins more than $5 \mathrm{~cm}$ distant from tumours. The results of our study regarding the GST activity also reveal a decrease in the activity of that enzyme in the tumour compared to the distal margin. It is believed that reactive oxygen species may cause enzyme deactivation in the course of carcinogenesis (Dursun et al., 2006; Dincer et al., 2007). A statistically significant reduction in the activity of these enzymes in patients with advanced clinical stage was also observed by Namyslowski et al. (2003) and by Manoharan et al. (2005). Assuming that advanced clinical stage is connected with increased oxidative stress, it may affect the activity of enzymes forming the antioxidant barrier. 
Numerous studies have reported disturbances in the antioxidant balance, but the data regarding changes in the antioxidant enzyme activity in various types of neoplasms are controversial (Rao et al., 2000; Stanczyk et al., 2005; Dursun et al., 2006; Ho et al., 2006; Hwang et al., 2007; Sharma et al., 2007; Klimczak et al., 2009; Pejic et al., 2009; Sharma et al., 2009). Dincer et al. (2007) and Dursun et al. (2006) suggest that changes in the activity of antioxidant enzymes may occur in response to metabolic changes and excessive production of free radicals as an expression of impairment of mitochondrial function in neoplastic cells.

The results of our study confirm the hypothesis of increased oxidative stress in the course of the neoplastic process. That is evidenced by high activity of antioxidant enzymes. The increase in the activity of antioxidant enzymes is an outcome of cellular adaptation to conditions of increased oxidative stress and has been described by many authors (Janssen et al., 2000; Czeczot et al., 2003; Wang et al., 2005; Hileman et al., 2004; Erata et al., 2005; Dursun et al., 2006; Dincer et al., 2007; Rainis et al., 2007). It is thought that the enhancement of the antioxidant enzyme activity is a result of the activation of genes that code for antioxidant enzymes by oxidants (Yokota, 2000; Skrzydlewska \& Stankiewicz, 2001; Zhou et al., 2003; Skrzydlewska et al., 2005).

An increase in SOD activity may be caused by induction of the corresponding gene, which is regulated by interleukin-1 (IL-1) and tumour necrosis factor alpha $(\mathrm{TNF}-\alpha)$. The activity of these signalling molecules may increase in neoplastic cells (Abele, 2002; Skrzydlewska et al., 2003; Hwang et al., 2007; Namysłowski et al., 2003). The results on GST activity suggest, in turn, an impairment of the enzymatic antioxidant barrier in neoplastic cells. This result may also be explained on the basis of observations made by other authors. In their opinion, changes in the activity of antioxidant enzymes may be a result of enzyme inactivation in the course of the carcinogenic process (Dursun et al., 2006; Dincer et al., 2007). Reactive oxygen species induce changes not only in nucleic acids, but also in lipids and proteins, including antioxidant enzymes. What is more, proteins that undergo such modification lose their biological activity. This hypothesis is particularly relevant to the actions of the hydroxyl radical (Waszczykowska et al., 1999; Evans et al., 2004). Stress induced by excessive production of reactive nitrogen species also leads to structural changes in proteins as a result of nitrosylation, which also translates into inhibition of their function (Klatt \& Lamas, 2000; Ridnour et al., 2004; Pylvas et al., 2010). Another hypothesis that aims to explain the causes of the high variability in the activities of the studied enzymes is a change in the expression of some genes in the course of neoplastic transformation, including genes encoding antioxidant enzymes whose expression may be increased or decreased (Stanczyk, 2005; Yokota, 2000).

Genes encoding various antioxidant enzymes, in particular the glutathione transferase isoenzymes, are highly polymorphic and often contain numerous mutations. A connection between the mutations or polymorphisms of those genes and an increase of the cancer development risk has been established in the oesophagus, stomach, large intestine, breasts, lungs and lymph nodes (Katoh et al., 1996; Stoehlmacher et al., 2002; Ho et al., 2006; Holley et al., 2006; Lightfoot et al., 2006; Kitteringham et al., 2007; Landi et al., 2007; Yao et al., 2010). Studies of the genetic polymorphism of GSTT1 and GSTM1 genes have revealed a high differentiation within the respective populations. GSTT1 has been shown to be polymorphic and is absent in 10-18\% of the population of Europe. Similarly, GSTM1 gene is absent in $38 \%$ of individuals (Olędzki \& Kędziora-Kornatowska, 2006). The vast majority of ROS-induced damage in cells is removed by repairing enzymes, however, some may accumulate and contribute to the mutagenesis. Moreover, the occurrence of mutations themselves does not result in development of malignancy. It is only when mutations occur in several genes of proliferating cells that the process of carcinogenesis may be initiated (Karihtala \& Soini, 2007). Mice with an inactivated CuZnSOD gene, in which the incidence of liver cancer has been observed to increase along with age, may serve as an example of the antioxidant defence system as a contributing factor in carcinogenesis (Elchuri et al., 2005). In studies by Chu et al. (2004), inactivation of two out of four GPx genes in mice, namely GP×1 and GP×2, resulted in the development of colorectal cancer; and mice with a decreased catalase activity had a higher incidence of breast cancer (Ishii et al., 1996). Furthermore, the gene expression is also affected by epigenetic alterations connected with methylation in their promoter regions. Reactive oxygen species are capable of modifying the pattern of DNA methylation (Klaunig \& Kamendulis, 2004). In our earlier studies in a group of patients with colorectal cancer, we observed DNA methylation of $p 16$ and MGMT genes both in tumour and corresponding normal mucosa (Krakowczyk et al., 2008). Kim et al. (2005) observed hypermethylation of GSTP1 gene promoter in adenomas and adenocarcinomas of sporadic colorectal cancer. GSTP1 gene promoter hypermethylation was recognised as a tumour marker for prostate, breast, kidney and gastric cancer (Esteller et al., 1998; Gonzalgo et al., 2003; Kim et al., 2005; Muller \& Brenner, 2006).

\section{CONCLUSIONS}

The change of antioxidant enzymes activities may result from the fact that neoplastic disease disturbs the balance in both ROS production, as well as in the efficiency of the antioxidant system of the organism. It is difficult to interpret the findings regarding the relation of the distance between the sampled margin and tumour. There have been no reports in the available literature on changes in the activity of antioxidant enzymes depending on the distance from the tumour. Despite finding a significant correlation for only one of the analyzed parameters, it may be surmised that changes in the metabolism of neoplastic cells affect cells of tissues adjacent to the tumour. However, a more in-depth analysis is required.

\section{REFERENCES}

Abele D (2002) Toxic oxygen: the radical life-giver. Nature 420: 27.

Bartsch H, Nair J, Owen RW (2002) Exocyclic DNA as oxidative stress markers in colon carcinogenesis: potential role of lipid peroxidation, dietary fat and antioxidants. Biol Chem 383: 915-921.

Bechtel W, Bauer G (2009) Modulation of intercellular ROS signaling of human tumor cells. Anticancer Res 29: 4559-4570.

Beevi SS, Rasheed MH, Geetha A (2007) Evidence of oxidative and nitrosative stress in patients with cervical squamous cell carcinoma. Clin Chim Acta 375: 119-123.

Beno I, Staruchova M, Volkovova K, Batovsky M (1995) Increased antioxidant enzyme activities in the colorectal adenoma and carcinoma. Neoplasma 42: 265-269.

Ceriello A (2006) Effects of macronutrient excess and composition on oxidative stress: relevance to diabetes and cardiovascular disease. Curr Atheroscler Rep 8: 472-476.

Cerutti PA (1994) Oxy-radicals and cancer. Lancet 344: 862-863.

Chu FF, Esworthy RS, Chu PG, et al (2004) Bacteria-induced intestinal cancer in mice with disrupted Gpx1 and Gpx2 genes. Cancer Res 64: 962-968. 
Craghill J, Cronshaw AD, Harding JJ (2004) The identification of a reaction site of glutathione mixed-disulphide formation on $\gamma \mathrm{S}$ crystallin in human lens. Biochem J 379: 595-600.

Czeczot H, Skrzycki M, Gawryszewska E, Podsiad M, Porembska Z (2003) Evaluation of antioxidant status in patients with primary hepatocellular carcinoma. Pol Merkur Lekarski 15: 118-122 (in Polish).

Dalle-Donne I, Rossi R, Giustarini D, Colombo R, Milzani A (2005) Is there a role for S-glutathionylation of proteins in human disease? IUBMB Life 57: 189-192.

Dalle-Donne I, Rossi R, Colombo R, Giustarini D, Milzani A (2006) Biomarkers of oxidative damage in human disease. Clin Chem 52 . 601-623.

Das S, Mahapatra SK, Gautam N, Das A, Roy S (2007) Oxidative stress in lymphocytes, neutophils, and serum of oral cavity cancer patients: modulatory array of L-glutamine. Support Care Cancer 15: 1399-1405.

Dincer Y, Himmetoglu S, Akcay T, et al (2007) Prognostic significances of oxidative DNA damage evaluated by 8-hydroksy-deoxyguanosine and antioxidant enzymes in patients undergoing resection of gastric and colon carcinoma. Neoplasma 54: 131-136.

Dudek H, Farbiszewski R, Rydzewska M, Michno T, Kozłowski A (2004) Evaluation of the activity of antioxidant enzymes and concentration of non-enzymatic antioxidants in human brain tumours. Wiad Lek 57: 16-19 (in Polish).

Dursun H, Bilici M, Uyanik A, Okcu N, Akyuz M (2006) Antioxidant enzyme activities and lipid peroxidation levels in erythrocytes of patients with oesophageal and gastric cancer. I Int Med Res 34: 193-199.

Ehardt JG, Lim SS, Bode JC, Bode C (1997) A diet rich in fat and poor in dietary fiber increases the in vitro formation of reactive oxygen species in human feces. I Nutr 127: 706-709.

Elchuri S, Oberley TD, Qi W, et al (2005) CuZnSOD deficiency leads to persistent and widespread oxidative damage and hepatocarcinogenesis later in life. Oncogene 24: 367-380.

Erata GO, Kanbagli O, Durlanik O, Bulut T, Toker G, Uysal M (2005) Induced oxidative stress and decreased expression of inducible heat shock protein 70 (ihsp70) in patients with colorectal adenocarcinomas. Jpn J Clin Oncol 35: 74-78.

Esteller M, Corn PG, Urena JM, Gabrielson E, Baylin SB, Herman JG (1998) Inactivation of glutathione S-transferase P1 gene by promoter hypermethylation in human neoplasia. Cancer Res 58: 4515-4518.

Evans MD, Dizdaroglu M, Cooke MS (2004) Oxidative DNA damage and disease: induction, repair and significance. Mutat Res 567: 1-61.

Gonzalgo ML, Pavlovich CP, Lee SM, Nelson WG (2003) Prostate cancer detection by GSTP1 methylation analysis of postbiopsy urine specimens. Clin Cancer Res 9: 2673-2677.

Habig W, Pabst M, Jacoby W (1974) Glutathione S-transferase, the first step in mercapturic acid formation. J Biol Chem 249: 7130-7139.

Halliwell B (2007) Oxidative stress and cancer: have we moved forward? Biochem J 401: 1-11.

Halliwell B, Gutteridge J (1999) Free radicals in biology and medicine. 3nd ed. New York: Oxford University Press.

Hileman EO, Liu J, Albitar M, Keating MJ, Huang P (2004) Intrinsic oxidative stress in cancer cells: a biochemical basis for therapeutic selectivity. Cancer Chemother Pharmacol 53: 209-219.

Ho JC, Mak JCW, Ho SP, et al (2006) Manganese superoxide dismutase and catalase genetic polymorphisms, activity levels, and lung cancer risk in Chinese in Hong Kong. I Thorac Oncol 1: 648-653.

Hofseth LJ, Hussain SP, Wogan GN, Harris CC (2003) Nitric oxide in cancer and chemoprevention. Free Radic Biol Med 34: 955-968.

Holley SL, Rajagopal R, Hoban PR, et al (2006) Polymorphisms in the glutathione S-transferase mu cluster are associated with tumour progression and patient outcome in colorectal cancer. Int J Oncol 28: 231-236.

Hwang TS, Choi HK, Han HS (2007) Differential expression of managanese superoxide dismutase, copper/zinc superoxide dismutase, and catalase in gastric adenocarcinoma and normal gastric mucosa. Eur J Surg Oncol 33: 474-479.

Humphries KM, Szweda PA, Szweda LI (2006) Aging: a shift from redox regulation to oxidative damage. Free Radic Res 40: 1239-1243.

Inayama M, Hashimoto N, Tokoro T, Shiozaki H (2007) Involvement of oxidative stress in experimentally induced reflux esophagitis and esophageal cancer. Hepatogastroenterology 54: 761-765.

Ishii K, Zhen LX, Wang DH, Funamori Y, Ogawa K, Taketa K (1996) Prevention of mammary tumorigenesis in acatalasemic mice by vitamin E supplementation. Jpn J Cancer Res 87: 680-684.

Janssen AML, Bosman CB, Kruidenier L, et al (1999) Superoxide dismutases in the human colorectal cancer sequence. I Cancer Res Clin Oncol 125: 327-335.

Janssen AM, Bomsan CB, van Duijn W et al. (2000) Superoxide dismutases in gastric and esophageal cancer and the prognostic impact in gastric cancer. Clin Cancer Res 6: 3183-3192.

Johansson LH, Borg LAH (1988) A spectrophotometric method for determination of catalase activity in small tissue samples. Anal Biochem 174: 331-336.
Kamp DW, Srinivasan M, Weitzman SA (2001) Cigarette smoke and asbestos active poly-ADP-ribose polymerase in alveolar epithelial cells. I Investig Med 49: 68-76.

Kanbagli O, Ozdemirler G, Bulut T, Yamaner S, Aykac-Toker G, Uysal M (2000) Mitochondrial lipid peroxides and antioxidant enzymes in colorectal adenocarcinoma tissues. Jpn J Cancer Res 91: 1258-1263.

Karihtala P, Soini Y (2007) Reactive oxygen species and antioxidant mechanisms in human tissues and their relation to malignancies. APMIS 115: 81-103.

Katoh T, Nagata N, Kuroda Y, et al (1996) Glutathione S-transferase M1 (GSTM1) and T1 (GSTT1) genetic polymorphism and susceptibility to gastric and colorectal adenocarcinoma. Carcinogenesis 17: 1855-1859.

Kekec Y, Paydas S, Tuli A, Zorludemir S, Sakman G, Seydaoglu G (2009) Antioxidant enzyme levels in cases with gastrointestinal cancer. Eur J Intern Med 20: 403-406.

Kim HC, Roh SA, Ga IH, Kim JS, Yu CS, Kim JC (2005) CpG island methylation as an early event during adenoma progression in carcinogenesis of sporadic colorectal cancer. I Gastroenterol Hepatol 20: $1920-1926$.

Kim J, Lee HS, Bae SI, Lee YM, Kim WH (2005) Silencing and CpG island methylation of GSTP1 is rare in ordinary gastric carcinomas but common in Epstein-Barr virus - associated gastric carcinomas. Anticancer Res 25: 4013-4020.

Kitteringham NR, Palmer L, Owen A (2007) Detection and biochemical characterisation of a novel polymorphism in the human GSTP1 gene. Biochim Biophys Acta 1770: 1240-1247.

Klatt P, Lamas S (2000) Regulation of protein function by S-glutathiolation in response to oxidative and nitrosative stress. Eur I Biochem 267: 4928-4944.

Klaunig JE, Kamendulis LM (2004) The role of oxidative stress in carcinogenesis. Annu Rev Pharmacol Toxicol 44: 239-267.

Klimczak A, Kubiak K, Malinowska K, Dziki L (2009) Activity of selected antioxidant enzymes examination in people with colorectal cancer. Pol Merkur Lekarski 27: 470-473.

Kondo S, Toyokuni S, Iwasa Y et al. (1999) Persistent oxidative stress in human colorectal carcinoma, but not in adenoma. Free Radic Biol Med 27: 401-410.

Krakowczyk L, Strzelczyk JK, Adamek B et al. (2008) Methylation of the MGMT and p16 genes in sporadic colorectal carcinoma and corresponding normal colonic mucosa. Med Sci Monit 14: BR 219225.

Landi S, Gemignani F, Neri M et al. (2007) Polymorphisms of glutathione S-transferase M1 and manganese superoxide dismutase are associated with the risk of malignant pleural mesothelioma. Int J Cancer 120: 2739-2743.

Laviano A, Meguid MM, Preziosa I, Fanelli FR (2007) Oxidative stress and wasting in cancer. Curr Opin Clin Nutr Metab Care 10: 449-456.

Lightfoot TJ, Skibola CF, Smith AG, et al (2006) Polymorphisms in the oxidative stress genes, superoxide dismutase, glutathione peroxidase and catalase and risk of non-Hodgkin's lymphoma. Haematologica 91: 1222-1227.

Lin MT, Beal MF (2006) Mitochondrial dysfunction and oxidative stress in neurodegenerative diseases. Nature 443: 787-795.

Liu X, Zhao J, Zheng R (2003) DNA damage of tumor-associated lymphocytes and total antioxidant capacity in cancerous patients. Mutat Res 539: 1-8.

Lu F (2007) Reactive oxygen species in cancer, too much or too little? Med Hypotheses 69: 1293-1298.

Manoharan S, Kolanjiappan K, Suresh K, Panjamurthy K (2005) Lipid peroxidation \& antioxidants status in patients with oral squamous cell carcinoma. Indian J Med Res 122: 529-534.

Muller H, Brenner H (2006) Urine markers as possible tools for prostate cancer screening: review of performance characteristics and practicality. Clin Chem 52: 562-573.

Namysłowski G, Sobczak A, Uhma E (2003) The activity of enzymatic antioxidant system depending on larynx cancer staging. Otolar Pol 57: 39-43.

Nicholson ML, Neoptolomes JP, Clayton HA, Talbor IC, Bell PR (1991) Increased cell membrane arachidonic acid in experimental colorectal tomours. Gut 32: 413-418.

Olędzki R, Kędziora-Kornatowska K (2006) Antioxidative mechanisms in human being. Valetudinaria — Post Med Klin Wojsk 11: 15-20 (in Polish).

Ozdemirler G, Pabuccuoglu H, Bulut T, Bugra D, Uysal M, Toker G (1998) Increased lipoperoxide levels and antioxidant system in colorectal cancer. I Cancer Res Clin Oncol 124: 555-559.

Patel JB, Shah FD, Shukla SN, Shah PM, Patel PS (2009) Role of nitric oxide and antioxidant enzymes in the pathogenesis of oral cancer. I Cancer Res Ther 5: 247-253.

Pejic S, Todorovic A, Stojiljkovic V, Kasapovic J, Pajovic SB (2009) Antioxidant enzymes and lipid peroxidation in endometrium of patients with polyps, myoma, hyperplasia and adenocarcinoma. Reprod Biol Endocrinol 7: 149.

Pelicano H, Carney D, Huang P (2004) ROS stress in cancer cells and therapeutic implications. Drug Resist Updat 7: 97-110. 
Pervaiz S (2006) Pro-oxidant milieu blunts scissors: insight into tumor progression, drug resistance, and novel druggable targets. Curr Pharm Des 12: 4469-4477.

Pylvas M, Puistola U, Kauppila S, Soini Y, Karihtala P (2010) Oxidative stress-induced antioxidant enzyme expression is an early phenomenon in ovarian carcinogenesis. Eur J Cancer 46: 1661-1667.

Rainis T, Maor I, Lanir A, Shnizer S, Lavy A (2007) Enhanced oxidative stress and leucocyte activation in neoplastic tissues of the colon. Dig Dis Sci 52: 526-530.

Rao GM, Rao AV, Raja A, Rao S, Rao A (2000) Role of antioxidant enzymes in brain tumours. Clin Chim Acta 296: 203-212.

Ray G, Batra S, Shukla NK et al. (2000) Lipid peroxidation, free radical production and antioxidant status in breast cancer. Breast Cancer Res Treat 59: 163-170.

Ray G, Husain SA (2002) Oxidants, antioxidants and carcinogenesis. Indian J Exp Biol 40: 1213-1232.

Ridnour LA, Thomas DD, Mancardi D et al. (2004) The chemistry of nitrosative stress by nitric oxide and reactive oxide species. Putting perspective on stressful biological situations. Biol Chem 385: 1-10.

Rao GM, Rao AV, Raja A, Rao S, Rao A (2000) Role of antioxidant enzymes in brain tumours. Clin Chim Acta 296: 203-212.

Roessner A, Kuester D, Malfertheiner P, Schneider-Stock R (2008) Oxidative stress in ulcerative colitis-associated carcinogenesis. Pathol Res Pract 204: 511-524.

Satomi A, Murakami S, Hashimoto T, Ishida K, Matsuki M, Sonoda M (1995) Significance of superoxide dismutase (SOD) in human colorectal cancer tissue: correlation with malignant intensity. J Gastroenterol 30: 177-182.

Savitha S, Tamilselvan J, Anusuyadevi M, Panneerselvam C (2005) Oxidative stress on mitochondrial antioxidant defense system in the aging process: Role of DL- $\alpha$-lipoic acid and L-carnitine. Clin Chim Acta 355: 173-180.

Seven A, Seymen O, Inci F, Oz B, Yigit G, Burcak G (2000) Evaluation of oxidative stress in experimental colitis: effects of L-arginine-nitric oxide pathway manipulation. I Toxicol Environ Health A 61: 167-176.

Sharma M, Rajappa M, Kumar G, Sharma A (2009) Oxidant-antioxidant status in Indian patients with carcinoma of posterior one-third of tongue. Cancer Biomark 5: 253-260.

Sharma A, Rajappa M, Saxena A, Sharma M (2007) Antioxidant status in advanced cervical cancer patients unergoing neoadjuvant chemoradiation. Br J Biomed Sci 64: 23-27.

Simmonds NJ, Allen RE, Stevens TRJ, van Someren RNM, Blake DR, Rampton DS (1992) Chemiluminescence assay of mucosal reactive oxygen metabolites in inflammatory bowel disease. Gastroenterology 103: 186-196.

Singh I (1997) Biochemistry of peroxisomes in health and disease. Mol Cell Biochem 167: 1-29.

Singh RP, Sharad S, Kapur S (2004) Free radicals and oxidative stress in neurodegenerative diseases: relevance of dietary antioxidants. JIACM 5: 218-225.

Skrzydlewska E, Kozuszko B, Sulkowska M et al. (2003) Antioxidant potential in esophageal, stomach and colorectal cancers. Hepatogastroenterology 50: 126-131.

Skrzydlewska E, Stankiewicz A, Sulkowska M, Sulkowski S, Kosacka I (2001) Antioxidant status and lipid peroxidation in colorectal cancer. J Toxicol Environ Health 64: 213-222.
Skrzydlewska E, Sułkowski S, Koda M, Zalewski B, Kanczuga-Koda L, Sulkowska M (2005) Lipid peroxidation and antioxidant status in colorectal cancer. World J Gastroenterol 11: 403-406.

Spitz DR, Sim JE, Ridnour LA, Galoforo SS, Lee YJ (2000) Glucose deprivation-induced oxidative stress in human tumor cells. A fundamental defect in metabolism? Ann N Y Acad Sci 899: 349-362.

Stanczyk M, Gromadzinska J, Wasowicz W (2005) Roles of reactive oxygen species and selected antioxidants in regulation of cellular metabolism. Int J Occup Med Environ Health 18: 15-26.

Stoehlmacher J, Park DJ, Zhang S et al. (2002) Association between glutathione S-transferase P1, T1, and M1 genetic polymorphism and survival of patients with metastatic colorectal cancer. J Natl Cancer Inst 94: 936-942.

Szatrowski TP, Nathan CF (1991) Production of large amounts of hydrogen peroxide by human tumor cells. Cancer Res 51: 794-798.

Tanaka M, Chock PB, Stadtman ER (2007) Oxidized messenger RNA induces translation errors. Proc Natl Acad Sci USA 104: 66-71.

Toyokuni S (1998) Oxidative stress and cancer: the role of redox regulation. Biotherapy 11: 147-154.

Valko M, Leibfritz D, Moncol J, Cronin MTD, Mazur M, Telser J (2007) Free radicals and antioxidants in normal physiological functions and human disease. Int J Biochem Cell Biol 39: 44-84.

Vanisree AJ, Shyamaladevi CS (1999) Status of lipid peroxidation and antioxidant enzymes in malignant (bronchogenic carcinoma) and non-malignant pleular effusions. Indian J Cancer 36: 127-134.

Violi F. Cangemi R (2005) Antioxidants and cardiovascular disease. Curr Opin Investig Drugs 6: 895-900.

Wang SH, Wang YZ, Zhang KY, Shen JH, Zhou HQ, Qui XY (2005) Effect of superoxide dismutase and malondialdehyde metabolic changes on carcinogenesis of gastric carcinoma. World J Gastroenterol 11: 4305-4310.

Waszczykowska E, Sysa-Jedrzejowska A, Choczaj-Kukula A (1999) Reactive oxygen species in cell physiology and pathology-therapeutic possibilities. Centr Eur J Immunol 24: 3-8.

Wiseman H, Halliwell B (1996) Damage to DNA by reactive oxygen and nitrogen species: role in inflammatory disease and progression to cancer. Biochem J 313: 17-29.

Yao S, Barlow WE, Albain KS et al. (2010) Manganese superoxide dismutase polymorphism, treatment-related toxicity and disease-free survival in SWOG 8897 clinical trial for breast cancer. Breast Cancer Res Treat 124: 433-439.

Yokota J (2000) Tumor progression and metastasis. Carcinogenesis 21: 497-503.

Zafirellis K, Zachaki A, Agrogiannis G, Gravani K (2010) Inducible nitric oxide synthase expression and its prognostic significance in colorectal cancer. APMIS 118: 115-124.

Zasadowski A, Wysocki A, Barski D, Spodniewska A (2004) Some aspects of reactive oxygen species (ROS) and antioxidative system agent's action. Short review. Acta Toxicol 12: 5-19.

Zimmerman R, Cerutti P (1984) Active oxygen acts as a promoter of transformation in mouse embryo C3H/10T1/2/C18 fibroblast. Proc Natl Acad Sci USA 81: 2085-2087.

Zhou Y, Hileman EO, Plunkett W, Keating MJ, Huang P (2003) Free radical stress in chronic lymphocytic leukemia cells and its role in cellular sensitivity to ROS-generating anticancer agents. Blood 101: 4098-4104. 